\section{Masalah Lingkungan, Pemanasan Global, dan Masa Depan Industri Kelapa Sawit Indonesia}

\section{Benny Dwika Leonanda}

Dosen dan Ketua PS PPI PPs Universitas Andalas, dan Dosen Jurusan Teknik Mesin Universitas Andalas

bdleonanda@gmail.com
Masalah lingkungan menjadi perhatian utama di dalam pertumbuhan ekonomi dunia. Terdapat kaitan erat antara lingkungan dengan produksi, dan ekonomi. Isu-isu pemanasan global menjadi isu sentral, dan mengancaman kegiatan ekonomi, produksi dan pertumbuhan ekonomi sebuah negara. Sistem ekonomi saat ini telah berubah, dan terbentuk sistem ekonomi baru yang berbasis kepada lingkungan dan kehendak konsumen. Proses pembangunan yang dijalankan pemerintahpun harus berubah, dan mengarah kepada pembangunan yang berkelanjutan. Demikian juga dengan proses produksi barang-barang harus mengarah kepada sistem bekerlajuntan. Sistem ekonomi yang masih memakai cara yang lama akan menghadapi hambatan, dan halangan. Dengan sendirinya pembangunan dan pertumbuhan ekonomi sebuah negara akan melambat. Tatatan ekonomi baru terbentuk dimana-dimana setiap rencana pembangunan harus berkelanjutan. Isu-isu lingkungan menjadi isu utama, dalam sistem produksi barang. Tidak ada jalan lain bari Pemerintah, dan badan usaha yang mengembangkan produksi dari bahan alam dan tergantung kepada kondisi alam untuk memenuhi tuntuntan ekonomi baru tersebut. Bagaimanapun tuntutan ekonomi tersebut akan berubah menjadi tuntutan politik, dan akan membuat regulasi-regulasi pembatasan perdagangan antar negara-negera. Sementara Indonesia sangat tergantung kepada sumber daya alam dan mengembangkan produksinya dengan menggunakan bahan alam dan kondisi alam. Sebagai akibatnya perekonomian Indonesia akan melambat, dan produksi berbagai industri akan terhambat.

Kata kunci : pemanansan global; industri, kelapa sawit

Dlpresentasikan: 30 Agustus 2019

Direvisi: 14 September 2019

Diterima: 2 Oktober 2019

Dipublikasikan online: 5 Oktober 2019

\section{Pendahuluan}

Masalah lingkungan menjadi perhatian utama di dalam pertumbuhan ekonomi dunia. Negara-negara maju menyadari bahwa memacu pertumbuhan ekonomi dan pembangunan berdampak langsung terhadap kerusakan lingkungan, dan kelangsungan hidup manusia. Pertumbuhan ekonomi di berbagai negara di dunia mengakibatkan produksi karbon semakin tinggi dan memicu pemanasan global (Haller, 2012). Banyak percaya bahwa negara-negara di Eropa terdampak langsung dalam hal ini.

Es-es di kutup Utara mencair dan minipis. Permukaan air laut menjadi tinggi, dan banyak terjadi banjir di daerah-daerah pantai akibat luapan air laut sebagai efek dari pemanasan global. Pemanasan global mengakibatkan musim panas semakin panjang. Badai ekstrim semakin sering terjadi dan lebih merusak. Gelombang-gelombang panas semakin sering dan berlangsung dalam waktu yang lama, semakin tinggi temperature di beberapa kawasan. Cuaca ekstrim, dan kelangkaan air minum, perubahan iklim, dan dampak- dampak lain yang merugikan manusia. Sebagai akibatnya kegiatan bisnis dan pertumbuhan ekonomi tersebut kembali menjadi ancaman bagi produksi, pertumbuhan ekonomi itu sendiri.

Memacu pertumbuhan ekonomi dan pembangunan tidak terlepas dari upaya pemerintah-pemerintah diberbagai negara untuk menciptakan kemakmuran. mengentaskan kemiskinan, dan menciptakan lapangan pekerjaan bagi penduduk di negara-negara tersebut. Dalam upaya meningkatkan pertumbuhan, berbagai sumber daya alam, pertambangan, pertanian, produksi barang dan jasa dipacu sedemikian rupa untuk memenuhi target dan kebutuhan di dalam negeri. Usaha-usaha tersebut tentu saja berakibat terhadap lingkungan, dan masyarakat secara langsung sebagai hasil akhir dari eksploitasi dan eksplorasi bahan alam. Kondisi ini memaksa terbentuknya sistem ekonomi baru yang ditentukan oleh kehendak konsumen sebagai pemakai akhir dari sebuah produk dari industri. Sistem ini dipakai untuk membatasi dan menjadi penghalang utama dalam sistem ekonomi modern saat ini yang mengancam produk-produk negara berkembang

Cara mensitasi artikel ini:

Leonanda, B. D (2019) Masalah Lingkungan, Pemanasan Global, dan Masa Depan Industri Kelapa Sawit Indonesia. [Edisi Khusus]. Buletin Profesi Insinyur 2(3): 102-107 
seperti Indonesia yang lebih berbasis kepada bahan alam ketimbang teknologi.

\section{Pembahasan}

Pertumbuhan Ekonomi dan Pembangunan

Pertumbuhan ekonomi dan pembangunan yang direncanakan pemerintah Indonesia tidak terlepas dari upaya untuk menciptakan kemakmuran dan mengentaskan kemiskinan rakyat Indonesia.Kemakmuran bisa dicapai jika lapangan pekerjaan tersedia, dan masyarakat memperoleh pendidikan dan kesehatan. Semua hal tersebut bisa terjadi jika ekonomi tumbuh dan berkembang. Perkembangan ekonomi akan memacu investasi dan membuka lapangan pekerjaan baru dan menuntut pendidikan lebih tinggi. Hal tersebut menumbuhkan dan menggiatkan ekonomi sebauah negara. Ekonomi tumbuh dan masyarakat menjadi lebih sejahtera (Nunez, 2019).

Pembangunan dan pengembangan dunia usaha atau investasi tidak terlepas dari pemanfaatan sumber daya alam. Sumber daya alam diperoleh secara langsung maupun tidak langsung di darat maupun di laut. Teknologi menyediakan cara bagaimana mengekspoitasi sumber daya alam, dan mengubahnya menjadi produk-produk bernilai ekonomi dan bermanafaat untuk kepentingan manusia. Berbagai dunia usaha akan tumbuh dan dan berkembangan mealalui investasi dalam negeri maupun dari luar negeri. Semuanya berebut mengeksploitasi berbagai sumber daya alam, untuk mengejar keuntungan dan memperbesar kapasitas dunia usaha mereka dan memperbesar kekayaan mereka.

Sumber daya alam adalah faktor yang penting dalam proses produksi. Bahan baku untuk proses produksi tersebut melalui Sistem Industri. Sumber daya alam mencakup tanah, air dan segala kandungan di dalamnya. Energi terbarukan dan sumber daya hayati (hewan dan tanaman) merupakan bagian dari sistem ini. Semua itu harus dipakai secara bijaksana sehingga keberlanjutannya dapat dipertahankan. Namun walaupun demikian di sisi lain kebutuhan-kebutuhan mendesak dan target-target politik sesaat pada masa pemerintahaan tertentu memaksa eksploitasi sumber daya alam secara berlebihan.

Di dalam Industri produksi merupakan aktifitas menghasilkan suatu produk dari sumber-sumber bahan baku menjadi bahan jadi sebagai output dari hasil produksi. Barang-barang yang diproduksi pada akhirnya dikonsumsi dan dipakai untuk melayani kebutuhan hidup manusia. Di banyak sektor, produksi dan konsumsi akan menyebabkan polusi dan memberi tekanan lain terhadap lingkungan yang menurunkan kualitas dan kuantitas lingkungan yang mendukung kehidupan. Kualitas dan kuantitas lingkungan menjadi buruk. Pada gilirannya akan mempengaruhi dan memperlambat pertumbuhan ekonomi sebuah negara dan berdampak langsung terhadap keamanan, kesehatan, keselamatan, dan kesejahteraan manusia di kawasan tersebut (Galeotti, 2003). Namun disisi lain eksploitasi sumber daya alam harus tetap dilakukan untuk memperoleh mineral, dan bahan bakar fosil, dan sumber-sumber energi lainnya sehingga proses produksi terus berlanjut untuk mencapai target-target pertumbuhan ekonomi negara.

Pencapaian target pertumbuhan ekonomi merupakan sebuah dilema yang harus dipecahkan secara bersama antara pemerintah, badan usaha, dan penduduk yang ada di sebuah negara. Pilihan-pilihan terhadap eksploitasi bahan alam seperti mineral, bahan bakar, serta berbagai pilihan lain tentu saja akan mengancam keberlansungan hidup di permukaan bumi. Satu sisi manusia membutuh bahan-bahan alam seperti mineral, bahan bakar fosil, dan sumber-sumber daya lain untuk mendukung dan menfasilitasi produksi, dan jasa yang dibutuhkan manusia. Di sisi lain setiap aktifitas produksi dan layanan bersifat ekonomi yang diberikan akan memberatkan atau mengancam keberlangsungan lingkungan.

Aktifitas produksi adalah di dalam menghasilkan barang dan jasa akan berakhir menjadi aktifitas ekonomi dan perdagangan yang menghasilkan pertumbuhan ekonomi suatu negara. Produk-produk yang dihasilkan berupa barang, dan penyedia berbagai fasilitas yang memberikan layanan kehidupan manusia. Sehingga kehidupan manusia bisa lebih mudah dan lebih sejahtera. Selain kebutuhan manusia terpenuhi, kesejahtaraan manusia juga tidak terlepas dari tersedianya lingkungan yang ramah terhadap kehidupan. Lingkungan menyediakan layanan lebih akan memungkinkan kegiatan ekonomi dapat berjalan dengan baik. Selain sebagai tempat hidup dan tempat tinggal, lingkungan juga akan berfungsi dan menfasilitasi penyerapan karbondioksida, penyaringan polusi udara, penyedia air, memberi perlindungan terhadap banjir, gelombang panas, dan menyediakan pembentukan tanah untuk bercocok tanam (UNDP, 2019).

Secara garis besar lingkungan terbagi atas dua. Lingkungan makro dan lingkungan mikro. Lingkungan makro mencakup kekuatan sosial yang terdiri dari demografi, ekonomi, fisik, teknologi, politik-hukum, dan sosial budaya. Semua hal tersebut mempunyai kaitan langsung dengan pertumbuhan ekonomi. Sementara lingkungan mikro adalah lingkungan skala kecil di mana makhluk hidup merupakan bagian dari organsisasi sebagai bagian yang berbeda dari lingkungan yang lebih besar. Lingkungan mikro ini lebih menjamin kelangsungan hidup jangka panjang yang mempengaruhi kebiasaan, dan keinginan manusia sebagai konsumen dari produk-produk yang dihasilkan dari kegiatan ekonomi.

\section{Resiko tinggi untung harus besar}

Sumber daya air, tanah, udara, biologi, hutan, perikanan yang merupakan aset produktif yang harus dijaga ketersediaannya dalam jangka waktu yang panjang. Semua hal tersebut terkait langsung dengan produktifitas ekonomi. Produktifitas ekonomi selain memproduksi barang dari berbagai sumber daya alam seperti mineral dan bahan bakar fosil, tidak terlepas dari kriteria apakah kegiatan tersebut akan sukses atau gagal di dalam usaha. Sukses atau gagalnya sebuah usaha tidak terlepas dari kinerja ekonomi, dan resiko yang akan mungkin timbul di belakang hari dari aktifitas ekonomi. Usaha-usaha yang beresiko tinggi biasanya 
membutuhkan pendanaan yang besar, dan lembaga penyedia modal menyediakan suku bunga tinggi. Suku bunga tinggi merupakan hal yang lazim suatu aturan di dalam pembiayaan untuk sebuah kegiatan beresiko tinggi menuntut keuntungan yang lebih besar dari pada kondisi normal (high risk, high profit).

Suku bunga tinggi merupakan sebuah hambatan lain dari investasi. Jika bunga/interest lembaga penyedia keuangan atau bank tinggi berbagai dunia usaha mengalami kesulitan dalam mengelola modal dan pruduksi. Biaya modal yang dikeluarkan untuk pinjaman tersebut akan berubah menjadi ancaman ketimbang pengembangkan dunia usaha. Dunia usaha akan terhambat, dan tidak berkembang, dan pengangguran meningkat.

Pengangguran tinggi di suatu negara, upah tenaga kerja menjadi murah, dan pendapatan per kapitapun menjadi rendah. Kondisi ini pada akhirnya jumlah orang miskin semakin bertambah besar, dan pada akhirnya kesejahteraan penduduk menjadi rendah. Pada kondisi kesejahteraan rendah setiap orang yang hidup di suatu negara akan bersikap brutal. Kekacauan bisa saja terjadi setiap saat, dan keamanan sebuah negara akan terganggu dan tidak terjaga. Sebagai akibatnya negara tidak stabil dan ekonomi negara tersebut tidak akan tumbuh. Kondisi ini tentu saja memparah keadaan ekonomi sebuah negara, dan semua hal tersebut terjadi jika semua sisi yang terlibat di dalam aktifitas bisnis termasuk dalam hal ini pemerintah dan badang usaha/swasta lebih terfokus pada keuntungan dan pembangunan jangka pendek. Pada akhirnya untuk mengatasi permasalahan baru yang muncul dibelakangan hari sebagai akibat dari kemunduran ekonomi diperlukan langkah-langkah baru yang bisa menjamin keuntungan dari sebuah proses produksi atau sistem industri. Pembangunan jangka panjang akan terabaikan, dan berkemungkinan atau tidak dapat dilanjutkan. Pembangunan jangka panjang hanya bisa diperoleh dengan konsep ekonomi lingkungan di dalam pembangunan.

Pembangunan ekonomi lingkungan mengacu kepada faktor ekonomi eksternal yang dibentuk konsumen, teknologi, dan peningkatan nilai. Seluruh dunia usaha harus bergerak menuhi kebutuhan tersebut, dan pada akhinrya hasil akhir dari pembangunan yang mempertimbangan factor lingkungan akan mempengaruhi kinerja dunia usaha. Faktor-faktor ini seringkali diluar kendali perusahaan, dan bahkan sebuah negara. Hal ini akan dapat berdampak pada skala besar (makro) atau skala kecil (mikro) dalam kehidupan berbangsa.

\section{Pembentukan pasar ditentukan oleh konsumen}

Penolakan sebuah produk dari industri merupakan kehendak dari konsumen, ketersediaan teknologi, dan sejauh mana sebuah pruduk ditingkatkan dan peningkatan nilai tidak mengancam lingkungan (Manyika dan Lund, 2019). Dibanyak keadaan, kehendak dari konsumen mempengaruhi politik, perdagangan, dan produksi sebuah produk dari industri di sebuah negara atau kawasan ekonomi. Sebagai contoh praktik pelabelan terhadap sebuah produk apakah label tersebut bersifat jaminan keamanan, kesehatan, kepercayaan terhadap sebuah Agama (misal Islam) seperti label Halal, atau bebas dari bahan-bahan yang berbahaya (misal air raksa) bagi kesehatan, kecantikan, atau lingkungan mempengaruhi produksi, sosial, dan politik disebuah negara.

Dalam hal penolakan produk-produk Kelapa Sawit Indonesia di kawasan ekonomi Uni Eropa tidak terlepas dari masalah lingkungan disamping kompitisi produk yang sejenis dibelakangnya. Pihak masyarakat ekonomi Uni Eropa menganggap dan menuduh Indonesia telah melakukan produksi kelapa sawit secara tidak wajar, tidak ramah lingkungan, dan tidak memenuhi standarstandar lingkungan Uni Eropa. Masyarakat ekonomi Uni Eropa menilai Indonesia telah kehilangan 55\% tutupan pohon di hutan primer dari tahun 2000 sampai dengan 2015 (lebih dari 4.5 juta hektar). Keadaan ini terjadi dilahan konsesi legal dibawah pengawasan pemerintah Republik Indonesia.

Dalam kurun waktu dua puluh tahun, telah terjadi di dalam mengkonversi lahan dalam jumlah besar-besaran untuk tanaman industri Kelapa Sawit, Pulp dan Kertas (masing-masingnya 1.5 juta hektar). Sehingga Indonesia kehilangan tutupan pohon $45 \%$ dari hutan Indonesia, dan menghancur 3,6 juta hektar lahan hutan. Sebagian besar terjadi pada perusahaan pemegang konsensi berizin (dan pada praktiknya mengolah lahan industri tersebut lebih dari pada yang diizinkan yang diberikan Pemerintah Indonesia). Tingkat panen yang tidak berkelanjutan, setiap hasil yang selesai masa panen, dan tidak penanaman kembali. Jaringan-jaringan perkebunan Kelapa Sawit kecil yang berkemungkinan masuk ke dalam rantai pasokan yang sama dengan kelompok perkebunan Kelapa Sawit yang besar.

Hal tersebut tentu saja akibat dari ekspansi besarbesaran dalam perkebunan Kelapa Sawit sejak tahun 2000 seiring peningkatan permintaan terhadap Kelapa Sawit yang tinggi akibat dari naiknya harga bahan bakar fosil pada saat itu. Pasar dunia bergejolak, berbagai negara kesulitan dalam mendapatkan sumber energi, dan menetralisir keadaan pasar energi.

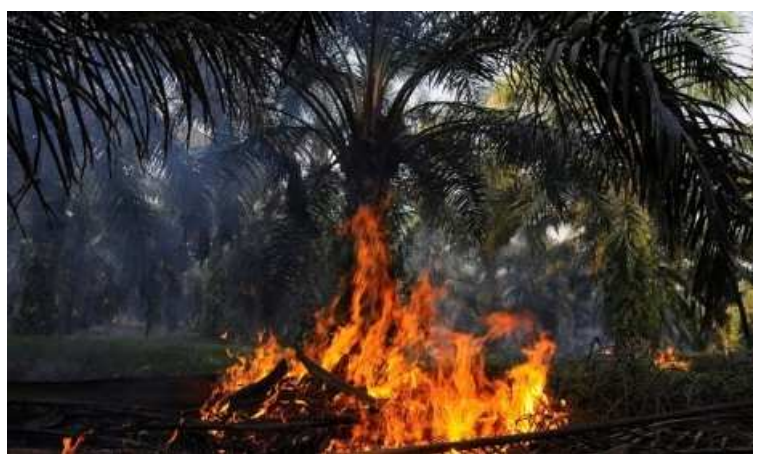

Gambar 1. [llustrasi] Kebakaran kebun kelapa sawit(Pratama, 2015)

Kondisi ini mengakibatkan berbagai negara mulai melirik untuk memanfaatkan energi baru dan terbarukan termasuk memakai bahan bakar terbarukan seperti bio-diesel yang berasal dari penambahan FAME (produk CPO) ke dalam bahan bakar Diesel. Ekpansi perkebunan kelapa sawit besar-besaran dan puncaknya terjadi pada awal-awal tahun pemerintahan Presiden Joko Widodo dan Jusuf Kalla di tahun 2014-2015. Setiap 
tahun Indonesia mengalami kebakaran hutan dalam jumlah besar dari pembukaan lahan perkebunan sawit di Pulau Sumatera, Kalimantan, dan Sulawesi. Kebakaran hutan yang terjadi 69.161,56 hektar ratarata lima tahun terakhir (2014-2018), yang mana puncaknya pada tahun 2015 mencapai 261.060,44 hektar. Menghancurkan hutan, dan sumber daya alam hayati di dalamnya dalam jumlah besar (Tayl, 2015).

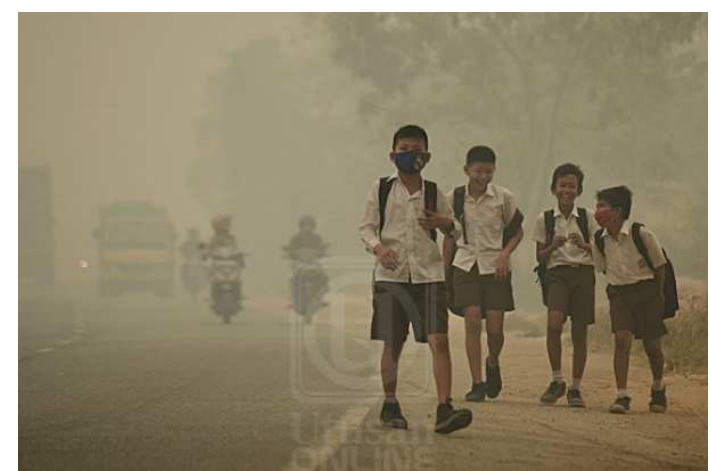

Gambar 2 Anak sekolah dipulangkan lebih awal dari sekolah, Jambi, photo Reuters. (Yusuf, 2015)

Kabut asap bukanlah hal yang aneh terjadi sepanjang tahun pada saat itu, dan mencapai puncak dimusim kemarau pada Februari sampai dengan Juli setiap tahun dan bahkan sampai pada Agustus. Penyebaran kabut asap tersebut sampai menganggu kesehatan, aktifitas pendidikan penduduk, dan dunia usaha dan bahkan penerbangan di berbagai Kota dan Provinsi di pulau-pulau besar Indonesia, dan bahkan sampai ke Negara-negara tetangga seperti Malaysia dan Singapura. Hal tersebut tentu saja memicu berbagai protes dari penduduk yang bermukim di pulau-pulau tersebut, dan bahkan sampai kepada pemerintahan Malaysia, dan Singapura.

Sebagai akibatnya Indonesia terpaksa mematuhi kesepatan untuk megurangi emisi hingga $70-90 \%$ dari tingkat bussines as usual (keadaan sekarang) sampai tahun 2030 yang diminta oleh Masyarakat Ekonomi Eropa. Hal ini jelas saja sebuah target yang berat untuk dicapai saat ini, karena sebagian besar produksi $\mathrm{CO}_{2}$ bukan saja dihasilkan oleh kebakaran hutan akan tetapi lebih banyak dihasilkan oleh mesin-mesin pembakaran dalam dari penggunaan bahan bakar fosil (minyak bumi). Mengingat produksi energi terbarukan Indonesia baru mencapai 12.5\% tahun 2018 ( PLTP 5\%, PLTA 7.27 $\%$, dan EBT 0,25\%). Kebutuhan akan pembangkit listrik baru yang ramah lingkungan menjadi tantangan tersendiri yang tidak mudah dilakukan dalam jangka waktu yang pendek. Kendala teknologi dan kebiasaan masyarakat di dalam pemakaian energi merupakan faktor utama yang akan menjadi kendala untuk menyelenggarakan hal tersebut.

Walaupun Masyarakat Ekonomi Uni Eropa masih membuka pasar mereka terhadap produk Kelapa Sawit Indonesia, namun Indonesia harus memenuhi ketentuan yang ditetapkan oleh Uni Eropa sampai tahun 2020 dimana produk-produk Kelapa Sawit Indonesia harus mencapai $100 \%$ produksi Minyak Sawit berkelanjutan. Pada masa itu setiap produk Sawit Indonesia sudah mempunyai Sertifikasi dengan skema- skema yang ada yang ditetap Bersama antara pemerintah Indonesia dan Uni Eropa. Sertifikasi ramah lingkungan terhadap sebuah produk bukan lah hal yang mudah untuk diperoleh perusahaan-perusahaan Indonesia. Setiap proses produksi harus memenuhi standar-standar yang telah ditentukan dan ditetapkan oleh pemberi layanan Sertifikasi. Sampai April 2019 baru 5.976 hektare perkebunan sawit masyarakat yang mengantongi sertifikat ISPO. Jumlah tersebut sekitar 0,1 $\%$ dari total perkebunan sawit rakyat saat ini seluas 5,8 juta hektare.

\section{Ancaman terhadap produk Kelapa Sawit}

Ancaman lain dari produk Kelapa Sawit Indonesia adalah Masyarakat Ekonomi Uni Eropa tidak akan membatasi atau melarang pemberian label bebas Kelapa Sawit atau Palm Oil-Free (PO-Free) yang akan dipasang diberbagai produk-produk yang diproduksi perusahaan-perusahan Eropa atau dari negaral lain yang dijuual di kawasan ekonomi eropa (EEAS, 2018). Terutama kepada setiap produk-produk yang di dalamnya terdapat berbahan dasar dari minyak nabati. Hal tersebut dianggap sebagai dari hak konsumen dan merupakan sebuah strategi pemasaran sebuah perusahan dalam menjual produk di pasaran sebuah negara atau kawasan ekonomi.

Pemberi label bebas berbahan dasar minyak kelapa sawit (Free Palm Oil) terhadap produk makanan atau produk lain seperti kosmetik di dunia merupakan hal yang lazim seperti halnya pemberian label-label lain seperti rendah atau tanpa gula (Sugar-Free), bebas modifikasi genetik organisme (GNO-Free). Hal tersebut tentu saja akan membatasi produksi dan pemasaran produk kelapa sawit yang beraasal dari Indonesia. Apalagi saat ini orang-orang Eropa (dan mungkin ditempat lain) saat ini mulai peduli memperhatikan kesehatan dan lingkungan. Mereka semakin kuatir terhadap produk-produk mereka konsumsi.
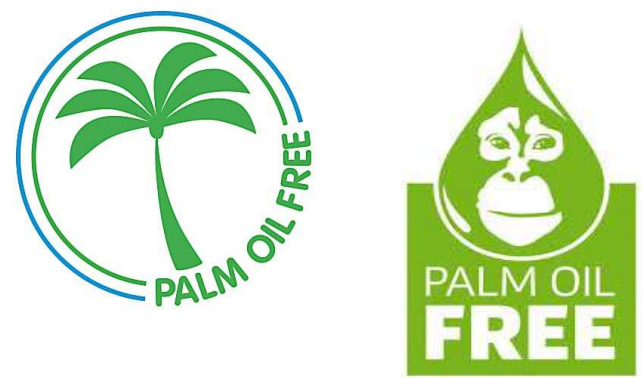

Gambar 2. Palm oil free label. A (biggreensmile.com ) (palm-oil-free.org )

Tidak ada jalan lain bagi pemerintah dan perusahaan-perusahaan Indonesia untuk mengikuti ketentuan-ketentuan Masyarakat Ekonomi Uni Eropa di dalam kesepakatan yang telah dibuat dengan pemerintah Indonesia. Tuntutan masyarakat Maysarakat Ekonomi Uni Eropa yang menuntut bahwa setiap produk dari kelapa sawit harus mengikuti prinsip ekonomi berkelanjutan yang berbasis terhadap lingkungan. Tuntutan masyarakat di Eropa tentu saja akan berubah menjadi tuntutan 
politik negara-negara di kawasan eropa, dan dan akan membuat regulasi-regulasi atau undangundang yang melakukan pembatasan perdagangan yang memakai produk Kelapa Sawit di negara-negara di Eropa. Sementara ekonomi Indonesia saat ini sangat tergantung kepada ekspor produk Kelapa Sawit, selain minyak bumi. Mengingat industri pertanian Indonesia sangat tergantung kepada produksi perkebunan kelapa sawit.

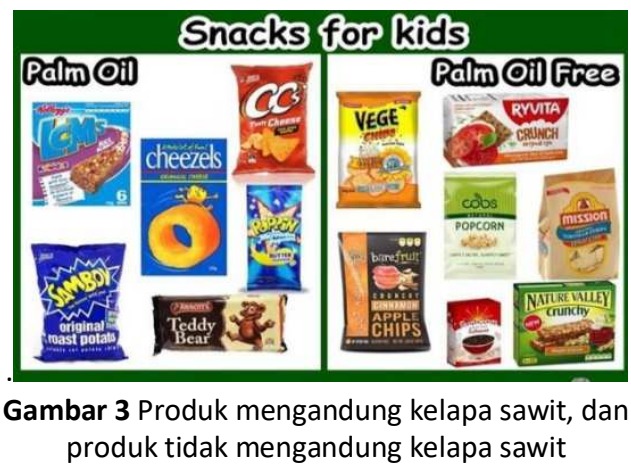

(id.pinterest.com)

Saat ini luas perkebunan Kelapa Sawit Indonesia mencapai 14.03 juta hektar. Sementara produksi kelapa sawit Indonesia mencapai 37,8 juta ton dengan ratarata produksi 3,6 ton per hektar. Bagaimanapun sebuah pasar modern saat ini lebih dan telah dibentuk oleh konsumen. Sementara industri Kelapa Sawit Indonesia menghidupi 16-20 juta orang penduduk Indonesia. Sementara dilain pihak perkebunan dan Industri Kelapa Sawit berhubungan langsung terhadap pengetasan kemiskinan, pengembangan masyarakat dan upaya global untuk mencapai target dalam pembangunan berkelanjutan. Sehingga Industri Indonesia harus terus tetap berlanjut untuk menopang target-target dari keberlanjutan pembangunan ekonomi Republik Indonesia.

Untuk menopang hal tersebut Indonesia harus membuat standar yang jelas dalam memproduksi produk-produk kelapa sawit, dan menegakan berbagai Peraturan dan Undang-undang yang baik dan dapat menjamin keberlanjutan pembangunan ekonomi lingkungan. Semua hal tersebut harus sejalan dengan Perjanjian Paris yang berhubungan dengan pengendalian perubahan iklim (Climate Change) dan Tujuan Pembangunan Berkelanjutan (SDGs) 2030. Indonesia harus membuat kebijakan dan penegakan hukum tentang penggunaan lahan yang tepat, dan dapat mencegah kerusakan lingkungan dan meningkat persepsi masyarakat ekonomi Uni Eropa dan penerimaan pasar Global.

Bagaimanapun Masyarakat Ekonomi Uni Eropa akan tetap terus mengeksplorasi hal-hal yang berkaitan dengan lingkungan hidup. Selain untuk memproteksi hasil pertanian dan industri dikawasan ekonomi eropa, juga mereka mereka mempunyai kepentingan atas kelangsungan hidup orang-orang di benua Eropa dalam ancaman terhadap pemanasan global, dan perubahan iklim. Setiap produk-produk yang dipasarkan ke kawasan Eropa berada di bawah pengaturan Maysarakat Ekonomi Uni Eropa. Konsep ini berlaku untuk negara-negara lain yang mengekspor produk mereka ke kawasan ekonoimi Eropa, termasuk Cina, dan India. Di dalam konteks komitmen-komitmen yang pembangunan ekonomi berkelanjutan, dan komitmenkomitmen akan melibatkan banyak negara di dunia yang menjadi tujuan ekspor Kelapa Sawit Indonesia. Bagaimanapun Masyarakat Ekonomi Eropa merupakan salah satu pasar global yang mempengaruhi pasar dunia. Hal tersebut tentu saja berdampak besar terhadap produksi Industri Indonesia yang diekspor ke kawasan ekonomi Uni Eropa dan negara-negara lain yang mengekspor produk mereka ke kawasan ekonomi Uni Eropa. Sehingga dapat dikatakan masa depan industri kelapa sawit Indonesia tergantung kepada kebijakan Pemerintah Indonesia dalam mengatur industri kelapa sawit di dalam negeri.

\section{Penutup}

Masalah lingkungan menjadi perhatian utama di dalam usaha memacu pertumbuhan ekonomi dunia saat ini. Negara-negara maju menyadari bahwa memacu pertumbuhan ekonomi dan pembangunan berdampak langsung terhadap kerusakan lingkungan, dan kelangsungan hidup manusia. Demikian juga dengan Indonesia, Pemerinah Republik Indonesia dalam usaha menciptakan kemakmuran, da mengentaskan kemiskinan juga berusaha untuk mengikatkan produksi salam negeri. Aktifitas produksi dalam usaha menghasilkan barang dan jasa akan berakhir menjadi aktifitas ekonomi dan perdagangan yang menghasilkan pertumbuhan ekonomi Indonesia. Produk-produk yang dihasilkan berupa barang, dan penyedia berbagai fasilitas yang memberikan layanan kehidupan manusia. Sehingga kehidupan manusia bisa lebih mudah dan lebih sejahtera. Selain kebutuhan manusia terpenuhi, kesejahtaraan manusia juga tidak terlepas dari tersedianya lingkungan yang ramah terhadap kehidupan baik dalam proses produksi, sampai dengan pemanfaatan hasil dari produksi

Aktifitas produksi barang dan jasa seringkali mengancam pembangunan jangka panjang. Pembangunan jangka panjang hanya bisa diperoleh dengan konsep ekonomi lingkungan di dalam pembangunan. Produk-produk dari industri yang menggunakan konsep ekonomi tidak berbasis lingkungan seringkali mengalami penolakan dari konsumen. Kehendak konsumen mempengaruhi politik, perdagangan, dan produksi sebuah produk di suatu negara atau kawasan. Sebagai contoh praktik pelabelan terhadap sebuah produk seperti halnya label halal atau label bebas dari bahan berbahaya. Label free palm oil merupapak penolakan dan ancaman terhadap produksi kelapa sawit yang tidak memakai pembangunan jangkan panjang dan tidak berbasis lingkungan.

Masyarakat ekonomi Uni Eropa pada dasarnya menolak produk kelapa sawit Indonesia, jika Indonesia tidak memenuhi ketentuan-ketentuan Masyarakat Ekonomi Uni Eropa pada masa akan datang. Setiap produsen kelapa sawit harus memenuhi persyaratan pembudidayaan kelapa sawit berkelanjutan (Ekarina, 2019). Tidak ada jalan lain bagi pemerintah dan Badan usaha (perusahaan-perusahaan) Indonesia untuk mengikuti ketentuan-ketentuan tersebut. Tuntututan 
Masyarakat Ekonomi Uni Eropa akan berdampak kepada tuntutan politik dan akan membuat regulasiregulasi pembatasan perdagangan yang memakai produk-produk yang tidak berbasis lingkungan. Bagaimanapun kawasan ekonomi Eropa merupakan salah satu pasar global yang mempengaruhi pasar dunia. Hal tersebut tentu saja berdampak besar terhadap produksi Industri Indonesia yang diekspor ke Uni Eropa dan negara-negara lain yang mengekspor produk mereka ke kawasan ekonomi Uni Eropa. Masa depan industri kelapa sawit Indonesia tergantung kepada kebijakan Pemerintah Indonesia dalam mengatur industri kelapa sawit di dalam negeri.

\section{Referensi}

EEAS (2018) European Union and Indonesia: Facts and Figures on Palm Oil, https://eeas.europa.eu/sites/ eeas/files/20180920_palm_oil_fact_sheet_en.pdf. 20 september 2018

Galeotti, M (2003) Economic Development and Environmental Protection. FEEM Working Paper No. 89.2003. 42 Pages, 25 Nov 2003

Haller, L.P (2012) Concepts of Economic Growth and Development. Challenges of Crisis and of Knowledge, Economy Transdisciplinarity Cognition. Vol. 15, Issue 1/2012, page 66-71.
Karina (2019) Hanya Sedikit Perkebunan Sawit Rakyat yang Tersertifikasi ISPO", https://katadata.co.id/ berita/2019/04/26/baru-01-perkebunan-sawitrakyat-yang-tersertifikasi-ispo

Manyika, J., Lund, S. (2019) The Next Era of Globalization Will Be Shaped by Customers, Technology, and Value Chains, https://hbr.org/2019/02/the-next-era-ofglobalization-will-be-shaped-by-customerstechnology-and-value-chains, February 12, 2019.

Nunez, C (2019) Causes and Effects of Climate Change, https://www.nationalgeographic.com/environment/ global-warming/global-warming-overview/, January 22, 2019

Pratama, Y. (2015) Industri Sawit Terpukul Dua Kali Akibat Kebakaran Hutan. https://environment-indonesia .com/industri-sawit-terpukul-dua-kali-akibatkebakaran-hutan/. September 22, 2015

Tayl, M (2015) As fires burn, can Indonesia avoid repeat of 2015 haze crisis?, https://www.reuters.com /article/ us-indonesia-politics-haze-analysis/as-firesburn-can-indonesia-avoid-repeat-of-2015-hazecrisis-idUSKCN1UVOZJ

UNDP (2019) That are the Sustainable Development Goals? https://www.undp.org/content/undp/en/ home/ sustainable-development-goals.html

Yusuf, M.K (2015) Indonesia perlu tiga tahun atasi jerebu, https://www.utusan.com.my/berita/nasional/indone sia-perlu-tiga-tahun-atasi-jerebu-1.141658\#sthash. TIdfuH4i.dpuf

-----, https://www.biggreensmile.com. Diakses 23 Juli 2019

-----, palm-oil-free.org. Diakses 23 Juli 2019

-----, https://id.pinterest.com. Diakses 23 Juli 2019 